\title{
DEVELOPMENT OF EMOTIONAL INTELLIGENCE IN THE ASPECT OF PERSONALITY DEVELOPMENT IN THE CONTEXT OF A LEARNING ORGANIZATION
}

\author{
Simas Garbenis \\ Vilnius University Siauliai Academy, Lithuania \\ Paulina Palujanskiene \\ Lithuanian Sports University, Lithuania
}

\begin{abstract}
Today's schools coexist with an environment that is constantly changing and shifting that is why modern schools should be open to new experiences, possibilities, become learning organizations. Also, educational institutions face the need for competencies in the formulation and implementation of competition policy, which in itself requires managerial knowledge based on an innovative approach. Moreover, the development of emotional intelligence integrated with the school curricula should be considered as one of the criteria for a school to become a learning school. Although some robust knowledge already exists about the positive impact of emotional intelligence development in educational settings. There is little to no research and theoretical data about the means to successfully integrate emotional intelligence development in schools as a context of learning organizations. Moreover, there is not any strong theoretical framework that links several ideas and theories on which they need for emotional intelligence development in learning schools could be based upon. Regarding this knowledge gap, this article aims to reveal the attitude of school staff about the development of emotional intelligence in the context of a school-learning organization. To achieve this goal, methods were used: scientific analysis of literature and documents and theoretical interpretations. Research results: peculiarities of emotional intelligence development in the context of personality development in the context of learning organization: how emotional intelligence is developed, its meaning and importance, possible perspectives, benefits for personality and organization-school in the context of learning organization (L. Vygotsky theoretical aspect). This justifies the need to organize personnel management and professional development processes in the development of emotional intelligence.
\end{abstract}

Keywords: school, emotional intelligence, learning organization, development.

\section{Introduction}

Nowadays when a traditional instructive and convictive method-based teaching does not always prove to be effective and efficient in various and constantly changing dynamic situations a new approach in regards to teaching 
throughout the organizational culture requires development (Lau, Lee, \& Chung, 2018). Today`s schools and other educational organizations coexist with an environment that is constantly changing, shifting, and evolving (Kvedaraite, 2009). This change led to a natural need for new competencies, resources, and teaching strategies (Kudokiene \& Juodaityte, 2005). In regards to these statements, modern schools should be able to meet modern educational requirements by becoming a learning organization and constantly apply various teaching strategies and methods. In our view, the development of emotional intelligence in modern schools, as learning organizations, should be integrated.

Emotional intelligence is a relatively new construct, but nowadays it is well known that people constantly experience a wide variety of emotions in their daily lives and that these emotions are one of the main factors that influence one `s behavior, decision making, thinking patterns, has a positive impact in various fields including education, etc (Dunn, 2016; Rafaila, 2015). Scholars with higher emotional intelligence tend to be more active and effective learners, have better relationships with peers and teachers, are less likely prone to antisocial behavior, perform better academically, etc. It is worth mentioning that emotional intelligence can be effectively developed through various social interactions, thus making moderns schools the ideal setting for its development. In other words, the development of emotional intelligence in schools should benefit them as learning organizations. Furthermore, emotional intelligence development is in a tie with the development of cognitive abilities which were thought to be the main priorities of schools.

Considering the newly found significance of emotions in an educational setting we imply that the development of emotional intelligence should be integrated into learning schools as a new teaching method or strategy. We found little to no research or theoretical data about how to (and based on what) effectively use and integrate this new teaching method or strategy. We aim to set a theoretical framework as a base for effective integration of the development of emotional intelligence as a new teaching method or strategy in a learning school context.

That is why the main goal of this article is to reveal the attitude of school staff about the development of emotional intelligence in the context of a schoollearning organization. To achieve this goal several research methods were used: scientific analysis of literature and documents, theoretical interpretations. By establishing the links and ties between the aspects of a learning organization (Palujanskiene \& Svagzdiene, 2020; Senge, 1990; Valuckiene, Balciunas, Katiliutè, Simonaitiene \& Stanikuniene, 2015), trait emotional intelligence structure and functions, (Petrides \& Furnham, 2001) and Vygotsky's (1982) main ideas of his cognitive development theory we believe new ideas about the 
effective integration and development of emotional intelligence in learning schools as learning organizations can be ascertained.

The work is based on the methods of integrated scientific literature analysis, general and logical analysis, analogy, complex generalization, and comparison.

\section{The Context of Schools as Learning Organizations}

There are several different characteristics of the content of learning organizations (Hester van Breda-Verduijn \& Heijboer, 2016; Örtenblad, 2018; Svagzdiene, 2010). One of the most profound contents of learning organizations is presented by P. Senge (1990), who is considered the pioneer of establishing learning organizations as a context. According to P. Senge (1990), the wholesome quality is determined not on the separate function effectiveness of learning organizations, but the compatibility and relativeness between those functions. These statements suggest that for schools to be considered learning organizations several functions that include the effectiveness of teaching and learning, various organizational areas of action should be interconnected and greatly compatible.

The analysis of scientific literature has revealed that it is crucial to determine separate attributes that should coexist to define the organization as a learning organization in different fields (Senge, 1990; Valuckiene et al., 2015). Schools however and their educational settings in a context of a learning organization should harmonize attributes both of the organizational structure action areas and the long-term learning cycle (Figure 1).

\begin{tabular}{|c|c|}
\hline $\begin{array}{c}\text { Organizational structure } \\
\text { action areas }\end{array}$ & Long-term learning cycle \\
\hline $\begin{array}{l}\text { Human resource } \\
\text { immersion }\end{array}$ & \\
\hline $\begin{array}{c}\text { Organization`s main ideas } \\
\text { and visions }\end{array}$ & \\
\hline Infrastructure novelties & 6 \\
\hline $\begin{array}{l}\text { Theory, methods and } \\
\text { various instruments }\end{array}$ & $\begin{array}{l}\text { Idividual } \\
\text { npetencies }\end{array}$ \\
\hline
\end{tabular}

Figure 1 Systemical Representation of a Learning School Attributes (adapted by authors from Palujanskiene \& Svagzdiene, 2020; Senge, 1990; Valuckiene et al., 2015) 
The connection presented in Figure 1 implicates how newly acquired experiences benefit one's individual and professional competencies. The possible result of this connection is not only the improvement of solitary skills but also the positive impact for the relationship between the individual and the organization, both way learning motivation, perception about the importance of working together, etc. This type of connection should greatly benefit students, empower them to learn, use various possibilities in/with the school and help the school itself to learn and constantly improve.

According to P. Juceviciene, a true learning organization is developed over a long time (Juceviciene, 2007). That is why long-term goals of potentially learning organizations become more like learning strategies and not singular goals or ideas. These strategies do not develop on their own. They are generated by the staff and the community of the organization, which means it is very important to focus not only on the infrastructure novelties but also on the search for new action, teaching-learning methods, human resources, and their use possibilities (Valuckiene et al., 2015).

In conclusion, we can state that learning organizations and their content can be perceived and is constructed differently by different authors. One of the most profound structures or attributes of learning organizations is presented by P. Senge (1990). This structure in correlation with a long-term learning cycle could be implied for schools to become learning organizations or learning schools. The analysis of scientific literature has revealed that for a school to become a learning school the most important aspect is not to improve solitary individual and organizational attributes, but to ensure the most significant and effective correlation, harmony between those attributes. A learning school then implies various learning methods, strategies that are beneficial to students in various ways. Such schools should be able to integrate the development of emotional intelligence for students. Such development may lead to a positive impact on student academic results, relationship quality, life quality in general and even prove useful for the schools as a learning organization`s attributes. That is why it is important to identify the theoretical framework for the successful integration of such development.

\section{Emotional Intelligence as a Learning School Indicator}

During the past two millennia emotions were thought to be of insignificant importance, "irrelevant" for proper decision making, and that the intelligence quotient is the main factor determining cognitive abilities (Dhani \& Sharma, 2016). Nowadays it is well known that people constantly experience a wide variety of emotions in their daily lives and that these emotions are one of the main factors that influence one`s behavior, decision making, thinking patterns, 
has a positive impact in various fields, including educational (Dunn, 2016; Rafaila, 2015).

As emotions gained more significant importance throughout the previous few decades the concept of emotional intelligence has caught the attention of various field researchers and academics. Nowadays four main theories submit a different definition of emotional intelligence and its structure (Bar-On, 1997; Goleman, 1995; Petrides \& Furnham, 2001; Salovey \& Mayer, 1990). In scientific literature, a decent number of differences between these theories are singled out, but in a broad sense, emotional intelligence can be defined as the ability to perceive emotional powers and to effectively dispose of them in everyday life.

A scientific literature analysis has revealed that this concept and its development has positive feedback for people in clinical, health, social and interpersonal, educational and vocational, organizational, and childhood fields (Petrides, Mikolajczak, Mavroveli, Sanchez-Ruiz, Furnham \& Pérez-González, 2016). In regards to the scope of the goal of this article, data about trait emotional intelligence and its development in organizational, educational, and vocational fields have been collected. We believe that the analysis trait emotional intelligence is most suited to reach the goal of this research. Trait emotional intelligence has a solid theoretical and empirical framework, which implies, that emotional intelligence is directly linked to personality traits (Petrides \& Furnham, 2001) and is defined as a constellation of emotional selfperceptions located at the lower levels of personality hierarchies and integrates the affective aspects of personality (Petrides, Pita, \& Kokkinaki, 2007). Trait emotional intelligence has various benefits not only for scholars as individuals but also for schools as learning organizations.

Studies have shown that trait emotional intelligence positively correlates with academic performance and behavior. In an educational or learning school context scholars with higher emotional intelligence are less likely to engage in maladaptive behavior patterns, drop out of school, and are more positively rated by their peers, teachers (Mavroveli, Petrides, Sangareau, \& Furnham, 2009). Furthermore, scholars with higher emotional intelligence can perform mildly better academically (Perera \& DiGiacomo, 2013; Siegling, Vesely, Petrides \& Saklofske, 2015). These statements suggest that scholars with higher emotional intelligence can be beneficial not only on the intrapersonal level but also on an organizational level. Such students should be more likely to engage in various new learning methods, be resourceful in achieving organizational learning strategies. Schools should consider these benefits and learn how to successfully integrate and carry out the development of emotional intelligence in constellation with the attributes of learning schools which were mentioned earlier. 
There are several studies conducted to determine whether or not trait emotional can be developed. Most of these studies suggest that trait emotional can be developed with long-lasting results for scholars in educational settings by various SEL programs, physical, social activities, etc. (Kaliska, 2019; Li \& Xu, 2019). Similar beneficial results can be achieved by trait emotional training in organizational settings. Such training empowers the staff to more effectively use their emotional powers in regards to their job requirements (Petrides, et. al., 2016). Teachers with higher emotional intelligence are potentially more effective in succeeding not only with their daily job tasks but in helping to develop trait emotional intelligence for their students.

In conclusion, we can state that emotional intelligence is a relatively new construct, but already gained major importance in various fields these past few decades. Emotional intelligence nowadays can be described and perceived differently, but in a broad sense, it can be defined as the ability to perceive and use one`s emotional powers. The development of trait emotional intelligence has been proven to be significant in various fields. In an educational field, the development of trait emotional intelligence is beneficial not only for scholars but for schools as learning organizations also. Since scholars with a higher emotional intelligence proven to be more academically and socially efficient. As in an organizational field, the importance of the development of trait emotional intelligence is vice-versa significant. This means that by developing teacher trait emotional intelligence not only they will be more efficient in carrying out the learning schools learning strategies, they will also have better abilities and perceptions on how to develop their student's trait emotional intelligence. Although there are several emotional intelligence training programs both in educational and organizational fields for them to succeed a wide variety of social interactions is required. In our view to successfully integrate and carry out the development of trait emotional intelligence in learning schools a robust understanding of social interactions and socialization is required.

\section{Connections between the Social Development of Emotional Intelligence in a Context of a Learning School}

As we mentioned earlier, we believe, that for a school to successfully become a learning school it should be able to constantly apply new teaching methods or strategies. We defined the development of emotions as one of such strategies hence its significance in educational and organizational fields. To successfully integrate and carry out such development a solid theoretical framework is in need. This framework should include the attributes of learning organizations (schools), the functions of trait emotional intelligence and its development possibilities through social interactions, and the main ideas of 
L. Vygotsky`s sociocultural theory since we find this theory closely related to the previous two criteria.

L. Vygotsky (Vygotsky, 1982) widely researched personality development and perception aspects which in most cases represented the importance of social and cultural environment, pedagogical help, mediation, mentorship for child development (Kereviciene, 2014; Pea \& Cole, 2019).

L. Vygotsky (1982) also proposed to research the social environment as the basis of personality development and developed these major ideas: 1) cognitive development is determined by social interactions and experiences; 2) children need constructive landmarks to learn and improve; 3) the rate of cognitive development depends on culture and time aspects; 4) children can learn independent of time if the ZPD is significant. This means that children while socially interact with adults are copying them by example, thus opening themselves for a deeper self-perception, learning and psychological development (Kereviciene, 2014). According to these statements and ideas, some robust theoretical links between learning schools, emotional intelligence development, and L. Vygotsky`s sociocultural theory ideas can be defined (Table 1).

Table 1 Theoretical Links between Learning Schools, L. Vygotsky's Sociocultural Theory Ideas, Trait Emotional Intelligence (adapted by authors from from Dunn, 2016;

Kaliska, 2019; Kerevičiene, 2014; Li \& Xu, 2019; Palujanskiene \& Svagzdiene, 2020; Pea \& Cole, 2019; Petrides et. al., 2016; Senge, 1990; Rafaila, 2015; Valuckiene et. al. 2015; Vygotsky, 1982)

\begin{tabular}{|c|c|c|}
\hline $\begin{array}{c}\text { Learning } \\
\text { school } \\
\text { attributes }\end{array}$ & $\begin{array}{c}\text { L. Vygotsky`s sociocultural } \\
\text { ideas }\end{array}$ & $\begin{array}{c}\text { Trait emotional intelligence } \\
\text { functions }\end{array}$ \\
\hline $\begin{array}{c}\text { Human } \\
\text { resource } \\
\text { immersion }\end{array}$ & $\begin{array}{c}\text { Teachers and staff in learning } \\
\text { schools should be provided with } \\
\text { abilities to acquire skills and } \\
\text { instruments to effectively socially } \\
\text { interact with scholars }\end{array}$ & $\begin{array}{c}\text { More effective social interactions } \\
\text { may teach scholars emotional self- } \\
\text { awareness, help them to adapt, build } \\
\text { self-esteem and motivation }\end{array}$ \\
\hline $\begin{array}{c}\text { Organization`s } \\
\text { main ideas } \\
\text { and visions }\end{array}$ & $\begin{array}{c}\text { Learning schools should include } \\
\text { personal development methods } \\
\text { and strategies }\end{array}$ & $\begin{array}{c}\text { Personal development strategies are } \\
\text { ideal for trait emotional intelligence } \\
\text { development hence it correlates with } \\
\text { personality traits }\end{array}$ \\
\hline $\begin{array}{c}\text { Infrastructure } \\
\text { novelties }\end{array}$ & $\begin{array}{c}\text { Learning schools should include } \\
\text { infrastructure novelties for } \\
\text { personal scholar development }\end{array}$ & $\begin{array}{c}\text { Infrastructure novelties such as focus } \\
\text { rooms, board games, smart devices } \\
\text { provide the possibilities for scholars } \\
\text { to use emotional intelligence } \\
\text { development programs, apps and } \\
\text { games }\end{array}$ \\
\hline
\end{tabular}


Garbenis \& Palujanskiene, 2021. Development of Emotional Intelligence in the Aspect of Personality Development in the Context of a Learning Organization

\begin{tabular}{|c|c|c|}
\hline $\begin{array}{l}\text { Theory, } \\
\text { methods and } \\
\text { various } \\
\text { instruments }\end{array}$ & $\begin{array}{l}\text { Learning organizations should } \\
\text { construct and coordinate their } \\
\text { visions based on scientific social } \\
\text { theories }\end{array}$ & $\begin{array}{l}\text { Organization`s actions based on } \\
\text { social theories empower the staff and } \\
\text { scholars for personal, interpersonal } \\
\text { emotional development through } \\
\text { socialization }\end{array}$ \\
\hline $\begin{array}{l}\text { Self-reflection } \\
\text { and feedback }\end{array}$ & $\begin{array}{l}\text { Learning schools should focus not } \\
\text { only on academic performance } \\
\text { feedback and self-reflection, but } \\
\text { on social also }\end{array}$ & $\begin{array}{l}\text { Social feedback is important for } \\
\text { scholars to understand their own, } \\
\text { other people emotional perspective } \\
\text { after various social situations }\end{array}$ \\
\hline $\begin{array}{l}\text { Knowledge } \\
\text { and perception }\end{array}$ & $\begin{array}{c}\text { Learning schools should } \\
\text { understand that cognitive } \\
\text { perception and knowledge is } \\
\text { dependent on social factors as } \\
\text { well }\end{array}$ & $\begin{array}{l}\text { Knowledge and perception about } \\
\text { emotions acquired during social } \\
\text { interactions may lead to a better } \\
\text { regulation of them in the future, } \\
\text { influencing cognitive performance }\end{array}$ \\
\hline $\begin{array}{c}\text { Individual } \\
\text { competencies }\end{array}$ & $\begin{array}{l}\text { Learnings schools should not only } \\
\text { focus on competencies that are } \\
\text { most significant for academic } \\
\text { achievement, but for social } \\
\text { competencies also }\end{array}$ & $\begin{array}{l}\text { Highly developed social skills and } \\
\text { competencies may lead to more } \\
\text { complex interactions. Complex social } \\
\text { interactions may provide more } \\
\text { opportunities learn how to control } \\
\text { one`s emotional potential }\end{array}$ \\
\hline $\begin{array}{l}\text { Individual } \\
\text { skills and } \\
\text { traits }\end{array}$ & $\begin{array}{l}\text { Learning schools should provide } \\
\text { the possibilities to improve } \\
\text { cognitive, psychological, social } \\
\text { skills in cohesion }\end{array}$ & $\begin{array}{c}\text { Individual skills and traits improved } \\
\text { through holistic teaching may help } \\
\text { create peer relations, low impulsivity, } \\
\text { etc }\end{array}$ \\
\hline $\begin{array}{l}\text { Beliefs and } \\
\text { views }\end{array}$ & $\begin{array}{l}\text { Learning schools should include } \\
\text { holistic, brave and long-term } \\
\text { views }\end{array}$ & $\begin{array}{l}\text { Long-term, holistic views regarding } \\
\text { education may include emotional } \\
\text { intelligence training aspects both for } \\
\text { scholars and staff }\end{array}$ \\
\hline
\end{tabular}

In Table 1 we mentioned only a few possible outcomes of successful integration of trait emotional intelligence development plan. We presented a chain of links between separate attributes of learning schools, sociocultural theory ideas, emotional intelligence functions, and how these links could coexist with traditional education goals, enriching schools and providing them the means to become learning schools in a field of trait emotional intelligence development.

\section{Discussion}

In our beliefs and views, most schools that operate nowadays only partly can be considered as learning organizations and there are several reasons for that. In our analysis, we mentioned that schools have some attributes to cover to be theoretically considered learning schools or a learning organization. In an educational context, these attributes cover both organizational and educational 
aspects. The majority of modern schools operate solely on academic achievements hence GPA, exam results, dropout rates, etc. are considered the ultimate factors determining the quality of the school. It is because of these factors a huge number of modern schools still focus on academic achievement. Schools base their vision, ideas, and actions to become more academically efficient thus neglecting social and emotional development factors. This may be due to insufficient knowledge about the co-benefits between academic achievements and other personal skills and traits. This lack of knowledge may be one of the reasons why a huge number of modern schools are yet to reach the status of a learning organization.

We are not surprised that the integration of emotional intelligence development in modern schools nowadays is considered highly important. It is a relatively new context and schools are often not ready for such integration to take place since older processes and beliefs are still present. Of course, there has been a notice that in recent years SEL programs, social, emotional competencies gained significant attention and importance for overall scholar development including academic achievements, yet we failed to find any theoretical framework about the effective integration of emotional intelligence development in schools. Most of the current research data and scientific literature describes the possible results and impact of various aspects of emotional intelligence development programs for scholars. Considering that emotional intelligence is becoming more and more relevant it is natural that more and more emotional development programs are being developed. Considering the wide variety of these programs we raised a question how do schools choose which program will be effective or the most effective hence they fail to meet the most criteria for learning schools and focus solely on academic achievements? As expected, there was no concrete answer and we fail that this integration is yet to be successful as it could be. There is little to no discussion that an emotional intelligence development program will be beneficial in some way, but without robust knowledge about how to harmonize learning school`s attributes with its vision, actions, emotional intelligence development methods these benefits can't be considered significant.

The theoretical framework that we presented in this article covers attributes of learning schools, social requirements for successful integration of trait emotional intelligence development. Please note, that this framework is subjective to our knowledge and perception about the areas we covered. Several other links and ties can be presented and generated, but we chose those, which we believe are most relevant for our goal. Based on our scientific literature analysis we were able to generate these main recommendations for schools to become learning organizations while successfully integrating the development 
Garbenis \& Palujanskiene, 2021. Development of Emotional Intelligence in the Aspect of Personality Development in the Context of a Learning Organization

of trait emotional intelligence:

1. It is recommended for schools to develop long-term visions and action plans that focus on holistic scholar development. Nowadays it is well known that cognitive abilities are not solely responsible for academic achievements and that emotional intelligence is significantly beneficial.

2. It is recommended for schools while generating new visions and action plans target most possible of the learning school's criteria to achieve. During the learning process, other criteria might well be met along the process.

3. These visions and action plans should be based on and cover clear, single theories and/or models. There are several different social development theories, emotional intelligence theories, and models. It is recommended for schools to choose these theories or models which are most relevant to their visions and action plans. Mixing theories and models will lead to partial, less significant results.

4. It is recommended for schools to create a wide variety of possibilities for their staff to develop personally, not professionally. More personally developed staff should be more competent during various social interactions and acquire some skills for a more effective scholar emotional intelligence development.

5. Constantly apply new teaching methods and strategies considering emotional intelligence and generate as much feedback and results as possible. According to these results, emotional intelligence development programs can be changed, modified. The same can be done with the learning school`s visions, action plans, etc.

\section{References}

Bar-On, R. (1997). BarOn emotional quotient inventory. Toronto: Multi-health systems.

Dhani, P., \& Sharma, T. (2016). Emotional intelligence: History, models and measures. International Journal of Science Technology and management, 5(7), 189-201.

Dunn, A. (2016). Social emotional development's effect on academic achievement of children with special needs. Unpublished Certificate of Advanced Study Thesis, Sacred Heart University, Fairfield, CT. Retrieved from http://digitalcommons.sacredheart.edu/ edl/13. Goleman, D. (1995). Emotional intelligence. New York City: Bantam Books, Inc.

Hester van Breda-Verduijn, H., \& Heijboer, M. (2016). Learning culture, continuous learning, organizational learning anthropologist. Industrial and Commercial Training, 48(3), 123-128.

Juceviciene, P. (2007). Besimokantis miestas. Monografija. Kaunas: Technologija.

Kaliska, L. (2019). Trait emotional intelligence development possibilities of primary schoolaged children. Education and New Learning Technologies 19 Proceedings, 9801-9807, DOI: 10.21125/edulearn.2019.2443. 
Kereviciene, J. (2014). Pedagogines psichologijos uzrasai. Kaunas. [Datafile]. Retrieved from https://www.knf.vu.lt/dokumentai/failai/katedru/germanu/vukhf_Kereviciene_ Pedagogines_psichologijos_uzrasai.pdf.

Kudokiene, N., \& Juodaityte, A. (2005). Mokyklos, kaip besimokancios organizacijos, formavimosi tendencijos. Jaunuju mokslininku darbai, 1(5), 34-42.

Kvedaraite, N. (2009). Šiuolaikines mokyklos kaip besimokancios organizacijos bruozu raiska personalo savivaldaus mokymosi sklaidos procesuose. Daktaro disertacija. Siauliai: Siauliu universitetas.

Lau, W. K., Lee, P. Y., \& Chung., Y. Y. (2018). A collective organizational learning model for organizational development. Leadership and Organization development Journal, 40(1), 107-123, DOI: https:// doi.org/10.1108/LODJ-06-2018-0228.

Li, C., \& Xu, J. (2019). Trait emotional intelligence and classroom emotions: A positive psychology investigation and intervention among Chinese EFL learners. Frontiers in psychology, 10, 2453, DOI: https://doi.org/10.3389/fpsyg.2019.02453.

Mavroveli, S., Petrides, K. V., Sangareau, Y., \& Furnham, A. (2009). Exploring the relationships between trait emotional intelligence and objective socio-emotional outcomes in childhood. British Journal of Educational Psychology, 79(2), 259-272.

Ortenblad, A. (2018). What does "learning organization" mean? The Learning Organisation, 25 (3), 150-158.

Palujanskiene, P., \& Svagzdiene, B. (2020). The paradigm of school as a learning organization: key features forming a modern organization. LASE Journal of Sport Science 2020, 11(1), 19-36. DOI: 10.2478/ljss-2018-0029 Retrieved from http://journal.lspa.lv/

Pea, R., \& Cole, M. (2019). The living hand of the past: The role of technology in development. Human development, 62, 14-39.

Perera, H. N., \& DiGiacomo, M. (2013). The relationship of trait emotional intelligence with academic performance: A meta-analytic review. Learning and Individual Differences, 28, 20-33.

Petrides, K. V., \& Furnham, A. (2001). Trait emotional intelligence: Psychometric investigation with reference to established trait taxonomies. European Journal of Personality, 15(6), 425-448.

Petrides, K. V., Mikolajczak, M., Mavroveli, S., Sanchez-Ruiz, M. J., Furnham, A., \& PérezGonzález, J. C. (2016). Developments in trait emotional intelligence research. Emotion Review, 8(4), 335-341.

Petrides, K. V., Pita, R., \& Kokkinaki, F. (2007). The location of trait emotional intelligence in personality factor space. British Journal of Psychology, 98(2), 273-289.

Rafaila, E. (2015). Primary school children's emotional intelligence. Procedia-Social and Behavioral Sciences, 203, 163-167.

Salovey, P. \& Mayer, J. D. (1990). Emotional intelligence. Imagination, Cognition, and Personality, 9, 185-211.

Senge, P. (1990). The fifth discipline: The Art and Practice of the Learning Organization. London: Century Business.

Siegling, A. B., Vesely, A. K., Petrides, K. V., \& Saklofske, D. H. (2015). Incremental validity of the trait emotional intelligence questionnaire-short form (TEIQueSF). Journal of Personality Assessment, 97(5), 525-535.

Svagzdiene, B. (2010). Turizmo paslaugos edukacinio potencialo raiska besimokancios organizacijos kontekste. Daktaro disertacija. Siauliai: Siauliu universitetas. 
Garbenis \& Palujanskiene, 2021. Development of Emotional Intelligence in the Aspect of Personality Development in the Context of a Learning Organization

Valuckiene, J., Balciunas, S., Katiliute, E., Simonaitiene, B., \& Stanikuniene, B. (2015). Lyderyste mokymuisi: teorija ir praktika mokyklos kaitai. Monografija. Siauliai: Siauliu universitetas.

Vygotsky, L. (1982). Razvytyje lychnosty y myrovozrenyja rebionka. Psyxologyja lychnosty. Moscow: University. 